\title{
PROFESIONALISME PUSTAKAWAN DALAM ERA DIGITAL
}

Oleh :

I Gusti Ayu Ketut Yuni Masriastri ${ }^{1,}$ Elekmida Sinaga $^{2}$

Insitut Agama Hindu Negeri Tampung Penyang ${ }^{1}$, Perpustakaan dan

Arsip Daerah Kalimantan Tengah

gustiyuni83@gmail.com¹, elekmidasinaga@yahoo.co.id

\begin{abstract}
Abstrak
Profesionalisme pustakawan dapat diartikan sebagai kegiatan perpustakaan yang dilaksanakan berdasarkan keahlian, tugas pokok dan fungsi dan yang utama adalah rasa tanggung jawab pustakawan sebagai pengelola perpustakaan. Tanggung jawab seorang pustakawan merupakan suatu proses kerja yang didasari rasa tanggung jawab dan bukan hanya sekedar pekerjaan yang menjadi rutinitas. Tanggung jawab dalam pekerjaan harus dibarengi dengan upaya-upaya untuk menghasilkan karya atau kinerja yang lebih baik lagi melalui prosedur kerja yang benar.

Tulisan ini membahas pengaruh era digital terhadap peningkatan profesionalisme pustakawan, dimana pustakawan sebagai ujung tombak kemajuan dan perkembangan perpustakaan. Oleh karena itu diharapkan membekali diri dan menggali potensi yang bermanfaat bagi organisasi induknya. Era digital merupakan tantangan berat bagi pustakawan tetapi sebaliknya mempermudah kegiatan kepustakawanan karena semua dikerjakan dengan digital. Sesuai latar belakang penulis seorang pustakawan (librarian) maka konsep era digital yang dibahas dalam tulisan ini diarahkan pada profesionalisme pustakawan.
\end{abstract}

Kata Kunci : Pustakawan, Profesionalisme, Era Digital, Teknologi dan Informasi

\section{Pendahuluan}

Kemajuan ilmu pengetahuan dan teknologi dalam era digital ditandai dengam adanya berbagai penemuan di berbagai aspek 
kehidupan yang mempermudah manusia dalam bekerja serta meledaknya informasi (information explotions). Seiring dengan itu kemajuan juga ditandai dengan adanya tuntutan dari berbagai aspek pekerjaan yang memerlukan kebutuhan informasi. Perkembangan ilmu pengetahuan, teknologi dan informasi membawa pengaruh terhadap perubahan-perubahan di bidang arus modernisasi dan sumbatansumbatan komunikasi di masyarakat.

Diharapkan kemajuan ilmu pengetahuan dan teknologi bisa membawa dampak yang baik serta meningkatkan kesejahteraan masyarakat. Hal ini erat kaitannya dengan peningkatan sumber daya manusia. Ini menjadi pekerjaan rumah bagi bangsa Indonesia yang sekarang sudah memasuki era masyarakat ekonomi Asean (MEA). Agar masyarakat Indonesia siap untuk bersaing dengan Negara lain di dunia kerja, maka sumber daya manusia harus ditingkatkan. Pustakawan merupakan salah satu profesi tersebut dan harus ikut andil dan megambil bagian dalam persaingan dunia kerja.

Berdasarkan undang-undang nomor 43 tahun 2007 tentang perpustakaan, pasal (1) menyatakan bahwa pustakawan adalah seseorang yang memiliki kompetensi yang diperoleh melalui pendidikan dan/atau pelatihan kepustakawanan serta mempunyai tugas dan tanggung jawab untuk melaksanakan pengelolaan dan pelayanan perpustakaan (Perpustakaan Nasional RI, 2010). Selanjutnya pasal 29, ayat (1) menyebutkan bahwa tenaga perpustakaan terdiri dari pustakawan dan tenaga teknis perpustakaan; yang dipertegas pada ayat (2) yang menyatakan bahwa pustakawan sebagaimana dimaksud pada ayat (1) harus memenuhi kualifikasi sesuai dengan standard nasional perpustakaan. 
Berdasarkan uraian diatas, maka profesionalisme pustakawan harus dilakukan oleh seorang pustakawan dengan kesadaran diri sendiri jika tidak ingin tersingkir dalam persaingan dunia kerja di era digital dan MEA. Pustakawan juga dituntut mempunyai kompetensi dibidangnya dan yang terpenting adalah profesional dalam melaksanakan tugas dan kewajibannya dibidang kepustakawanan dan diharapkan mampu memberikan layanan berkualitas dan prima yang bisa memberikan kepuasan bagi pengunjung perpustakaan.

Profesionalisme harus dimiliki oleh seorang pustakawan. Selain itu ada sisi yang tidak kalah penting yang merupakan bagian tidak terpisahkan dari pustakawan yaitu kepribadian (personality). Profesionalisme dan personality merupakan dua hal yang sangat penting bagi pustakawan dan saling berkaitan satu sama lain. Konsep profesionalisme dan kepribadian pustakawan merupakan konsep lama yang pernah ada, diagendakan dan diterapkan. Seiring berjalannya waktu dan perkembangan teknologi informasi konsep tersebut seolaholah hilang begitu saja. Padahal pustakawan merupakan pintu terdepan dalam memberikan layanan kepada pengunjung, khususnya pustakawan dibagian layanan yang berhubungan langsung dengan pengunjung. Mereka seharusnya mempunyai profesinalisme dan kapribadian yang baik seperti bagaimana cara melayani pengunjung, berbicara, berbusana, memberikan informasi dan sebagainya.

Profesi pustakawan tidak hanya dituntut cakap dan gesit dalam melaksanakan pekerjaan tetapi mempunyai kepribadian yang baik. Untuk menjadi tersebut diatas tidaklah mudah, tidak seperti membalik telapak tangan. Diperlukan kemauan dan usaha keras untuk mencapainya. Ada tiga hal yang selayaknya dimiliki oleh pustakawan 
yaitu berkepribadian unggul, inklusif dan humanis (Rhoni, 2017). Humanis artinya memanusiakan orang lain dan tidak mengobjekkan orang lain. Humanis dapat diartikan seseorang yang mempunyai sifat mendambakan dan memperjuangkan hidup yang lebih baik berdasarkan kemanusiaan atau seseorang yang mengabdikan dirinya untuk kepentingan orang lain.

\section{Pembahasan}

\section{Profesionalisme Pustakawan}

Kata profesional berasal dari kata profesi berasal dari bahasa latin, yaitu professues yang artinya suatu usha atau kerja yang semula dihubungkan dengan suatu janji dan sumpah yang mempunyai sifat religious. Profesi adalah pekerjaan dengan keahlian khusus sebagai mata pencaharian yang bersifat tetap yang memerlukan keterampilan, teori dan diuji oleh sebuah lembaga berwenang dan memberikan hak kepada yang bersangkutan untuk berhubungan dengan nasabah, Sulistyo Basuki dalam (Sujatna, 2018). Pekerjaan merupakan aktifitas kerja yang mendapatkan imbalan ataupun tidak, sedangkan profesi adalah pekerjaan dalam pengertian khusus dengan persyaratan khusus juga.

Agar dapat dikatakan sebagai profesi, maka pekerjaan harus mencerminkan dukungan berupa standard kualifikasi, pengabdian pada masyarakat, pengakuan oleh masyarakat, dan adanya organisasi profesi. Profesi mengandung arti suatu pekerjaan yang memerlukan pengetahuan khusus dibidangnya. Pustakawan dengan kemampuan professional yang dimiliki harus mampu dan sanggup memberikan pelayanan maksimal kepada pengunjung dan memajukan serta 
mengembangkan perpustakaan dengan mengikuti perkembangan ilmu pengetahuan dan teknologi.

Pustakawan adalah seseorang yang melaksanakan kegiatan perpustakaan dengan cara memberikan layanan kepada masyarakat sesuai dengan tugas perpustakaan induknya berdasarkan pengetahuan, dokumentasi serta informasi yang dimiliki yang diperoleh melalui pendidikan dan pelatihan (Sujatna, 2018). Menurut (Suwarno, 2010) pustakawan merupakan salah satu tiang perpustakaan, maka di tuntut untuk profesional dalam segala bidang kepustakawanan sesuai keahliannya. Pustakawan juga merupakan individu yang hidup dan melakukan semua kegiatan kepustakawanan artinya ketika profesi sebagai pustakawan disandang maka secara otomatis profesi tersebut melekat pada dirinya.

Profesionalisme pustakawan dapat diartikan sebagai kegiatan perpustakaan yang dilaksanakan berdasarkan keahlian, tugas poko dan fungsi dan yang utama adalah rasa tanggung jawab pustakawan sebagai pengelola perpustakaan. Keahlian merupakan faktor utama dan penentu dalam menghasilkan suatu karya dan menyelesaikan setiap permasalahn yang mungkin muncul dalam prosesnya. Tanggung jawab seorang pustakawan merupakan suatu proses kerja yang didasari rasa tanggung jawab dan bukan hanya sekedar pekerjaan yang menjadi rutinitas. Tanggung jawab dalam pekerjaan harus dibarengi dengan upaya-upaya untuk menghasilkan karya atau kinerja yang lebih baik lagi melalui prosedur kerja yang benar.

Menurut (Hartono, 2016) profesionalisme pustakawan adalah pelaksanaan kegiatan perpustakaan yang didasari oleh rasa tanggung jawab dan pengabdian, keahlian yang dimiliki serta mutu hasil kerja 
yang tidak dapat dihasilkan oleh tenaga yang bukan pustakawan. Pustakawan harus mengembangkan kemampuan dan keahlian yang dimiliki dalam menghasilkan mutu kerja yang lebih baik lagi kedepan. Keahlian merupakan dasar dalam menghasilkan suatu pekerjaan yang tidak semua orang bisa menghasilkannya, dan dengan keahlian yang dimiliki pustakawan dapat menyelesaikan masalah kepustakawan yang mungkin tidak dapat diselesaikan orang lain. Tanggung jawab pustakawan merupakan suatu kegiatan yang dilakukan pustakawan yang tidak hanya sekedar melakukan tugas rutin tetapi melakukan kegiatan bermutu yang hasilnya bisa dipertanggung jawabkan.

Kalau dilihat dari kondisi perpustakaan di Indonesia maka banyak pustakawan yang belum bekerja secara maksimal dan professional, mereka masih berada di pola pikir birokratis dan belum mampu melihat kedepan serta tidak ada keinginan untuk meningkatkan kemampuan diri khususnya di bidang kepustakawanan. Permasalah diatas disebabkan oleh beberapa hal antara lain :

a. Masalah penghayatan profesi

Menurut Mahmud dalam (Yahya, 2013) profesi merupakan suatu pekerjaan yang didasarkan atas keahlian dari pelatihan dan pendidikan khusus yang bertujuan memberikan pelayanan kepada masyarakat dengan imbalan penghasilan yang telah ditentukan. Pustakawan seharusnya memahami pengertian diatas agar dalam menjalankan tugasnya sesuai dengan profesinya. Pada umumnya pustakawan di Indonesia masih belum mampu menghayati profesinya. Hal ini disebabkan kurangnya pemahaman terhadap profesi sehingga pustakawan tidak mampu bekerja secara professional dan tidak punya rasa percaya diri. Jika mereka 
menghayati dan memahami profesinya maka akan meningkatkan kemampuan diri, mengikuti perkembangan ilmu pengetahuan dan teknologi, mandiri serta yang terpenting mampu bekerja dalam satu tim (team work).

b. Masalah jiwa kewiraswastaan

Pustakawan Indonesia pada umumnya belum memiliki jiwa kemandirian dalam mengembangkan inisiatif dan kreatifitas kerjanya. Kondisi inilah yang membuat pustakawan tidak memiliki jiwa wiraswasta.

c. Masalah keahlian integritas

Memiliki keterpaduan antara keahlian teknis dan keterampilan merupakan harapan kita bagi pustakawan Indonesia. Kenyataan yang kila lihat sekarang hal tersebut masih jauh dari harapan. Pustakawan yang bekerja di organisasi perpustakaan selalu memerlukan kualifikasi dan tidak hanya kualifikasi teknis seperti marketing informasi, jasa informasi, namun harus memiliki keterampilan manajerial seperti planning, organizing, staffing, directing, coordinating, reporting dan budgeting. Jika hanya memiliki keterampilan teknis tetapi tidak didukung dengan keterampilan manajerial maka tidak cukup untuk menjadi pustakawan professional.

d. Masalah bahasa

Pustakawan umumnya belum memiliki kemampuan dalam penguasaan bahasa asing. Bahasa merupakan kunci ilmu pengetahuan (language is the key scince) yang dapat digunakan sebagai alat bantu untuk memahami berbagai bidang ilmu pengetahuan karena pustakawan harus mampu mengkomunikasikan 
isi bahan pustaka/ informasi kepada pengunjung. Penguasaan bahasa asing diperlukan oleh pustakawan Indoensia di masa kini dan masa depan.

e. Penguasaan teknologi informasi

Ditinjau dari perspektif masyarakat umum, teknologi merujuk kepada peralatan modern yang canggih (Akadun, 2009). Menurut (Sutopo, 2012) teknologi informasi meliputi segala hal yang berkaitan dengan proses, penggunaan sebagai alat bantu, manipulasi, dan pengelolaan informasi. Dilihat dari pengertian diatas teknologi informasi berpengaruh di segala elemen kehidupan. Perpustakaan khususnya pustakawan tidak bisa menutup diri dari perkembangan teknologi informasi. Tidak bisa dipungkiri masih banyak pustakawan Indonesia yang tidak menguasai teknologi informasi dan mereka bekerja masih dengan sistem konvensional. Pustakawan sebagai bagian masyarakat ilmiah harus mampu mengikuti perkembangan ilmu pengetahuan dan teknologi. Kemampuan ini diperlukan karena pustakawan merupakan salah satu profesi penyaji ilmu pengetahuan yaitu sebagai penyaji ilmu pengetahuan dan informasi yang relevan, muktahir dan yang diperlukan oleh pengunjung karena tuntutan pengunjung perpustakaan biasanya mencari informasi yang cepat, tepat, akurat dan muktahir.

f. Motivasi kerja

Motivasi diartikan sebagai dorongan dasar yang menggerakkan sesorang bertingkah laku (Uno, 2007). Dorongan ini berada pada diri seseorang yang menggerakkan untuk melakukan sesuatu yang sesuai dengan dorongan dalam dirinya. Oleh Karena itu perbuatan 
seseorang yang didasarkan atas motivasi tertentu mengandung tema sesuai dengan motivasi yang mendasarinya.

Dalam menjalankan tugasnya seorang pustakawan akan memiliki ciri-ciri dan karakteristik tersendiri yang menunjukkan professional atau tidaknya dalam bekerja. Ciri-ciri profesionalisme pustakawan antara lain :

a) Memiliki ilmu pengetahuan, keterampilan, kecakapan dan keahlian yang handal dalam bidangnya.

b) Memiliki sifat mandiri

c) Memiliki kemampuan untuk berkolaborasi dan bekerjasama dengan orang lain.

d) Dalam bekerja berorientasi pada jasa dan menjunjung kode etik pustakawan.

e) Berani bermimpi dan mempunyai orientasi untuk kemajuan ke depan.

Profesionalisme pustakawan dalam bekerja sangat diperlukan karena cara kerja yang berprinsip pada people based service (berbasis pengguna) akan menghasilkan layanan prima yang akan berpengaruh terhadap kepuasan pengunjung. Dengan memiliki sikap professional pustakawan akan mendapat dampak positif yaitu peran dan keberadaan pustakawan akan semakin diapresiasi oleh banyak kalangan sehingga pustakawan tidak dipandang sebelah mata lagi.

\section{Kompetensi Pustakawan}

Kompetensi merupakan tolak ukur untuk mengetahui sejauh mana kemampuan dan keahlian seseorang dalam memanfaatkan pengetahuan dan kemampuannya. Kompetensi yang diperlukan oleh 
pustakawan dapat dibagi menjadi dua jenis yaitu kompetensi professional dan kompetensi perorangan (Salmubi, 2005). Kompetensi ini dikelompokkan menjadi tiga bagian, yaitu :

a. Kompetensi sebagai mekanisme strategi.

b. Kompetensi sebagai tindakan yaitu kontrol atas kinerja dari pengetahuan yang dimiliki.

c. Kompetensi sebagai budaya yaitu perilaku yang dilakukan untuk merespon pengaruh masyarakat.

Kompetensi pustakawan pada hakekatnya merupakan kemampuan, pengetahuan dan ketrampilan, sikap, nilai perilaku serta karakteristik untuk melaksanakan pekerjaan dan memberikan layanan kepada pengunjung (Hermawan \& Zen, 2006).

Pustakawan juga dituntut berkompeten dalam penguasaan ilmu pengetahuan dan teknologi. Masalah yang dihadapi oleh pustakawan di Indonesia adalah kurang menguasai bahasa asing dan kurang akrab dengan perkembangan teknologi komunikasi dan informasi. Hal ini mengakibatkan pustakawan menjadi kelompok mareginal di tengahtengah masyarakat informasi, karena komunikasi sekarang ini lebih memanfaatkan teknologi informasi. Dalam masyarakat informasi seperti sekarang pustakawan harus bisa menyesuaikan diri dan tanggap akan perubahan yang terjadi. Perpustakaan dewasa ini harus menggunakan aplikasi di semua bidang. Hal ini bertujuan agar perpustakaan mengikuti perkembangan teknologi dan informasi serta semakin mudah dalam memberikan layanan kepada pengunjung.

Budaya kompetisi antar sesama pustakawan di Indonesia masih sangat rendah. Pustakawan Indonesia masih sangat sederhana pola pikirnya serta mendasarkan diri hanya pada kepentingan pribadi, 
bahkan lupa bahwa perpustakaan merupakan pusat sumber informasi. Seperti misalnya sikap ketidakpedulian, berperilaku seenaknya, tidak berperan aktif dalam pendayagunaan informasi yang tersedia di perpustakaan.

Pustakawan profesional berarti bahwa pustakawan harus memiliki pendidikan dan pengetahuan di bidang kepustakawanan yang memadai. Pendidikan ini merupakan upaya penguasaan ilmu pengetahuan dan keahlian seorang pustakawan. Pendidikan dan keahlian ini hendaknya ditingkatkan terus sesuai dengan perkembangan ilmu pengetahuan dan teknologi serta tuntutan profesi. Selain itu, pustakawan harus memiliki wawasan yang luas. Hal ini bisa didapatkan dari kegiatan gemar membaca dan menulis, terampil, cerdas, tanggap, dan berorientasi kedepan.

Profesionalisme pustakawan memegang peranan penting dalam kemajuan dan perkembangan organisasi induknya. Untuk menjadi pustakawan profesional ada beberapa hal yang harus dilakukan yaitu :

a. Etika profesi

Etika merupakan ilmu tentang norma, nilai dan ajaran yang luas. Etika bersifat rasional, kritis, mendasar, sistematis dan normatif. Profesi pustakawan memerlukan kompetensi, ini karena etika merupakan sarana untuk memperoleh orientasi kritis yang berhadapan dengan moralitas. Di satu sisi, etika ingin menampilkan keterampilan intelektual yaitu keterampilan untuk beragumentasi secara kritis dan raisonal. Kode etik merupakan sistem, norma, dan aturan professional tertulis yang secara tegas menyatakan apa yang benar dan baik dan apa yang benar dan tidak baik bagi profesional. Tujuan kode etik sebenarnya adalah untuk mengatur ruang gerak 
para profesional agar memberikan jasa sebaik-baiknya kepada pemakai dan mencegah dari perbuatan yang tidak profesional.

Kode etik pustakawan merupakan pijakan awal bagi para profesional di bidang perpustakaan (pustakawan) dalam melaksanakan tugasnya, yang didalamnya memberikan pedoman tingkah laku yang dapat menghindarkan diri dari tindakan yang tidak profesional (Suwarno, 2010). Untuk memahami kode etik pustakawan, perlu disampaikan mengenai etika dan hal lain yang berkaitan dengan profesi pustakawan.

b. Kemandirian

Kemandirian merupakan keadaan di mana individu memiliki sikap dan perilaku yang terarah pada dirinya sendiri lebih lanjut dinyatakan bahwa kemandirian memiliki lima komponen yaitu : (1) Bebas artinya bertindak atas kehendak sendiri (2) Progress artinya mampu berpikir dan bertindak atas kehendak sendiri (3) Terkendali dari dalam artinya kemampuan individu dalam mengatasi masalah, mengendalikan tindakannya, dan mempengaruh lingkungan, serta kemantapan diri. Seseorang yang tidak professional tidak akan pernah dikenal dan kurang mampu memberikan manfaat kepada masyarakat. Mereka akan terpinggirkan cepat atau lambat.

c. Kesejawatan

Kesejawatan profesi pustakawan diatur dalam kode etik pustakawan Indonesia BAB III (kewajiban kepada organisasi dan profesi) dan BAB IV ( kewajiban antara sesame pustakawan). Pada BAB III disebutkan bahwa setiap pustakawan hendaknya menjadikan Ikatan Pustakawan Indonesia sebagai forum kerja sama, tempat konsultasi, tempat penggemblengan pribadi, meningkatkan ilmu dan 
mengembangkan profesi. Pustakawan diharapkan memberikan sumbangan tenaga, pikiran kepada organisasi untuk pengembangan ilmu dan perpustakaan di Indonesia.

d. Tanggung jawab moral

Seorang professional terpanggil untuk melaksanakan tugas dan tanggung jawab. Mereka memiliki tanggung jawab moral untuk mengembangkan ilmu perpustakaan dan kepustakawanan. Ilmu perpustakaan merupakan salah satu ilmu pengetahuan yang sangat penting dalam kehidupan bermasyarakat.

e. Organisasi profesi

Organisasi profesi ini bertujuan untuk meningkatkan profesionalisme, melindungi anggota profesi, menentukan dan mengatur pelaksanaan kode etik profesi, menyalurkan aspirasi, dan meningkatkan kesejahteraan anggota.

f. Teknologi informasi

Di era teknologi informasi, kegiatan perpustakaan harus memiliki kompetensi teknologi informasi yang meliputi pemanfaatan komputer, penguasaan database, penguasaan peralatan teknologi informasi, penguasaan teknologi jaringan/computer network, penguasaan intranet dan internet dan penguasaan bahasa asing.

g. Kemampuan berkomunikasi ilmiah

Kemampuan berkomunikasi secara lisan dan tulisan diperlukan untuk pengembangan pribadi dan profesi. Kelihaian menyampaikan dan menguasai materi dalam suatu seminar misalnya, akan mempengaruhi citra seorang pustakawan. Demikian pula dengan kemampuan menulis akan berpengaruh terhadap reputasi. Hanya 
sedikit pustakawan Indonesia yang mempunyai kemampuan berkomunikasi ilmiah kebanyakan hanya menerima dan pasif.

Berdasarkan uraian di atas, pustakawan sebagai tenaga fungsional memiliki peluang berperan aktif dalam dunia pendidikan seperti mengajar, menyuluh, membimbing, memberikan konsultasi, menjadi editor dan penyunting, maupun sebagai narasumber dalam pertemuan ilmiah di bidang perpustakaan, dokumentasi dan informasi.

\section{Kepribadian Pustakawan}

Pengembangan kepribadian pustakawan merupakan sifat hakiki seseorang yang mengalami perubahan kearah yang lebih baik, demi terwujudnya kepribadian diri yang dapat di terima oleh lingkungannya dalam segala situasi. Pustakawan akan mempunayi kepribadian yang baik jika memiliki 3G yaitu Good (Behavior, Appearance, Performance).

Pustakawan akan dapat merasakan betapa besarnya manfaat mengetahui pribadinya. Salah satu cara memahami pribadi adalah dengan melakukan introspeksi diri. Dalam berpenampilan pustakawan sebaiknya menerapkan yang dikenal denga 3S (sederhana, serasi, dan sopan). Begitu juga untuk membentuk pribadi yang unggul, inklusif, dan humanis, pustakawan harus memiliki POWER yaitu positif, others, world, expanse, dan realistic.

\section{Pengaruh dan Penghambat Kepribadian Pustakawan}

Menurut (Sedharmayanti, 2014) faktor kebiasaan dan tingkah laku, kemampuan berbicara, kesehatan dan sikap yang menunjang 
pelaksanaan tugas merupakan faktor yang mempengaruhi kepribadian. Beberapa factor lain yang juga berpengaruh terhadap kepribadian pustakawan adalah pendidikan (formal, informal), kelamin, pembawaan dan pengalaman, keluarga, agama, masyarakat, dan lingkungan.

Sementara factor yang menjadi penghambat yaitu fiksasi, frustasi, kurang pergaulan dan wawasan, sombong, dan rendah diri. Upaya pengembangan kepribadian pustakawan (be yourself) merupakan kalimat bijak yang layak untuk direnungkan dan pertimbangkan. Menjadi diri sendiri mengandung pengertian bahwa kita harus memahami bahwa tidak ada seorang pun yang mampu untuk mengerti dan menghargai diri kita selain kita sendiri.

Dengan demikian kepribadian itu menyangkut diri pribadi seseorang secara keseluruhan. Pengembangan pribadi merupakan salah satu cara dan upaya yang dilaksanakan untuk tercapainay peningkatan mutu. Kepribadian selalu dapat dikembangkan ke arah yang lebih baik melalui proses belajar. Beberapa hal yang berkaitan dengan upaya pengembangan kepribadian pustakawan antara lain :

a. Introspeksi dan evaluasi diri.

How I am? siapa saya, pertanyaan ini bagi pustakawan merupakan keyakinan, pandangan atau penilaian pustakawan terhadap dirinya sendiri. Hal ini dapat berupa penilaian secara fisik, fsikis, sosial, dan moral yang terbentuk melalui proses belajar sejak kecil hingga dewasa. Cara untuk memahami diri dapat dilakukan antara lain dengan pengenalan diri, memahami diri, dan mengetahui kelebihan dan kekurangan diri. 
b. Identitas dan jati diri

Identitas dan jati diri mempunnyai pengertian yang berbeda. Identitas adalah tanda diri kita, yang menunjukkan siapa kita, tetapi hanya menampilkan hal-hal secara lahiriah yang belum tentu menunjukkan pribadi yang sesungguhnya.

Sementara itu, jati diri merupakan siapa diri kita sesungguhnya. Jati diri merupakan sifat dasar manusia. Menurut (Soemarno, 2014) jati diri dalam tatanan kepribadian secara utuh dibagi menjadi 3 yaitu (1) nilai tersier yang dididik, dibentuk, dan dipengaruhi lingkungan dan dapat diubah. (2) nilai sekunder yang didapat secara genetik, dan sulit diubah. Misalnya bakat, kecerdasan, dan temperament. (3) nilai primer yang asli dan diperoleh dari Tuhan.

\section{c. Character Building}

Pembentukkan watak merupakan proses yang tidak ada hentinya (character building is a never ending process). Jika watak seseorang menunjukkan normative yang mengisyaratkan norma tingkah laku yang menjadi dasar individu dan perbuatannya. Pola pikir membentuk watak yang dimulai dari diri sendiri, keluarga, lingkungan, masyarakat serta nusa dan bangsa.

\section{d. Mind Set}

Dalam bekerja pustakawan harus mempunyai target pencapaian, sehingga jelas arah kerjanya di perpustakaan. Tanpa arah yang jelas pustakawan akan terjebak pada rutinitas kerja dan terjebak pada kondisi stress dan ekstitensi monoton. Pustakawan harus mampu membedakan antara kebutuhan yang mendesak dan penting. Untuk menjadi pustakawan profesional maka harus mengubah mind set karena merupakan cara berpikir dan kunci sukses. 


\section{e. Etiket}

Bagi pustakawan etiket berarti persetujuan bersama untuk menilai kesopanan seorang pustakawan dalam bergaul. Pustakawan harus yakin bahwa cara membawa dirinya akan menentukan kepribadian dalam bergaul dan bekerja.

Pustakawan diharapkan dapat memahami kepribadiannya sendiri dan berusaha menimbulkan kekuatan atau sisi kepribadian positif yang dimilikinya. Kepribadian yang dimiliki oleh pustakawan khususnya di bagian layanan akan sangat berpengaruh terhadap citra perpustakaan karena pustakawan langsung berhadapan dengan pengunjung.

\section{Kompetensi Pustakawan di Era Digital}

Lingkungan informasi elektronik di mana pustakawan bekerja banyak mengalami perubahan terutama dalam bidang akses informasi. Kecepatan dalam memperoleh dan mancari informasi, menganalisis dan menghubungkan informasi, teknologi yang terus mengalami perkembangan. Hal itu menjadi tuntutan bagi pustakawan untuk menjadi pustakawan professional dengan mengembangkan diri, selalu mengikuti perkembangan ilmu pengetahuan dan tenologi informasi agar bisa mengabdikan diri di bidang kepustakawanan.

Dengan kemajuan teknologi informasi, pustakawan harus bisa menjadi pribadi tangguh, artinya pustakawan harus siap dan mampu untuk menghadapi perubahan perpustakaan konvesional menjadi perpustakaan digital yang sekarang sedang berkembang di seluruh dunia. Informasi sudah menjadi bagian yang tidak terpisahkan dari 
masyarakat modern khususnya di perpustakaan, yang merupakan salah satu tempat dan sumber informasi bagi masyarakat.

Di era digital ini, pustakawan akan memainkan peran yang lebih dinamis ketimbang sekarang yang kebanyakan hanya sebagai pemandu bagi pengunjung yang membutuhkan informasi. Munculnya informasi digital merupakan kesempatan untuk meningkatkan peran pustakawan yang nantinya diharapkan akan muncul generasi-generasi pustakawan milenial yang dinamakan cyber librarian, yang sering juga disebut sebagai seseorang yang ahli dalam menemukan informasi di internet.

Menurut Oscar Berg dalam (Sujatna, 2018) menyatakan bahwa ruang kerja digital mempunyai enam (6) pilar yang berdiri secara sejajar dalam menopang ruang kerja supaya dapat berdiri dengan kokoh yang dapat dijabarkan sebagai berikut :

a. Manusia merupakan sentral

Era digital ditandai dengan munculnya dan pemanfaatan teknologi baru yang memerlukan kualifikasi yang berbeda khususnya dalam pengelolaan perpustakaan dan pusat-pusat informasi yang lain. Hal ini bertujuan supaya pekerjaan yang awalnya dikerjakan secara manual dan konvensional selanjutnya dikerjakan secara digital. Digitalisasi merupakan proses untuk memasukkan kode-kode digital binary yang nantinya menghasilkan suatu informasi. Peran pustakawan atau ahli informasi dalam hal ini sangat penting karena merupakan aktor dalam setiap penggunaan teknologi informasi. Ia adalah objek dari setiap aksi yang dilakukan oleh perpustakaan.

b. Mobilitas

Dunia digital menawarkan dunia dalam genggaman, hal ini membrikan dorongan kepada pustakawan agar bekerja dengan 
mobilitas tinggi. Pustakawan dapat bekerja dimanapun dan kapanpun. Ini artinya era digital seharusnya mampu menciptakan pustakawan professional dan tangguh di bidangnya dengan mobilitas kinerja tinggi. Dengan kata lain dunia digital mampu meningkatkan produktifitas kerja pustakawan.

c. Sistem Layanan

Era digital ditandai dengan pesatnya arus informasi digital di segala bidang kehidupan. Perpustakaan dihadapkan dengan kompetisi yang tinggi dengan perpustakaan lain. Semua lapisan masyarakat bisa menjadi sumber informasi dan ditampilkan secara on line, setiap orang bisa membuat perpustakaan pribadi secara virtual yang dapat diakses dimanapun dan oleh siapapun, ditambah dengan banyaknya search engine yang dengan mudah dapat digunakan sebagai alat pencari informasi.

Salah satu indikator keberhasilan suatu perpustakaan menjadi pusat sumber informasi adalah tigkat kunjungan dan penggunaan informasi yang dimiliki perpustakaan. Oleh karena itu perpustakaan harus berinovasi untuk meningkatkan jumlah pengunjung, sehingga perubahan perpustakaan konvensional menjadi perpustakaan digital menjadi lebih bermakna dan bermanfaat bagi masyarakat.

d. Kesederhanaan

Dunia digital memberikan beragam kemudahan bagi masyarakat sehingga pustakawan dapat memberikan pelayanan yang mudah dan sederhana. Menyederhanakan proses yang rumit, mempermudah yang sulit, mempercepat layanan (memberikan layanan prima), dan menciptakan suasana kekeluargaan di perpustakaan antara pengunjung dan pustakawan. Pustakawan harus bisa memberikan 
layanan prima sehingga menambah nilai positif di masyarakat, serta menciptakan lingkungan yang kondusif untuk bekerja.

e. Sosial (kemasyarakatan)

Oscar Berg dalam (Sujatna, 2018) menyatakan bahwa social (kemasyarakatan) tidak sesederhana teknologi. Oleh karena itu ruang digital harus mempunyai desain yang sesuai dengan kebutuhan manusia sebagi makhluk individu maupun tim kerja. Ada 5 (lima) hal yang harus diperhatikan agar ruang digital lebih manusiawi yaitu:

- Keterbukaan dalam mengakses informasi

- Transparansi dalam menggali informasi

- Apabila memungkinkan, mendukung partisipasi setiap orang karena kita akan berhadapan dengan berbagai macam masalah dan kesempatan.

- Adanya ruang dialog agar komunikasi berjalan efektif dan mencapai kesepakatan di dalam pemahaman dan tindakan.

- Adanya pengakuan untuk memberikan motivasi bagi mereka yang berkontribusi dan berpartisipasi.

\section{f. Kesinambungan}

Perpustakaan dan masyarakat merupakan dua hal yang tidak dapat dipisahkan. Perpustakaan sebagai fasilitasi proses belajar sepanjang hayat, oleh karena itu perpustakaan harus lebih diberdayakan agar mampu mempengaruhi masyarakat dan menjadi community sehingga mampu mendorong masyarakat menjadi melek informasi. Hal ini tidak terlepas dari peran pustakawan sebagai relationship manager. Untuk mencapai hal tersebut maka dibutuhkan 
profesionalisme pustakawan khususnya dalam era digital karena pengunjung perpustakaan kedepan berasal dari digital natives.

\section{Pustakawan Kreatif Inovatif di Era Digital.}

Banyak pendapat keliru tentang pustakawan selama ini. Pendapat tersebut menyatakan bahwa pustakawan hanya menjadi penjaga buku. Hal tersebut tidak semuanya benar dan tidak semua salah, bisa saja karena selama ini yang mereka lihat pustakawan identik dengan penunggu buku. Hal tersebut bisa ditepis oleh pustakawan dengan membuktikan diri bahwa mereka mempunyai tugas dan tanggung jawab yang lebih dari sekedar menjaga buku. Disinilah letak urgensi pustakawan untuk mengembangkan diri dan membangun kreatifitas yang inovatif.

Pustakawan kreatif inovatif tidak hanya sebatas menyusun dan mendata buku atau melayani pengembalian dan peminjaman buku. Pustakawan kreatif inovatif adalah pustakawan yang mampu membuat program serta terobosan yang mampu membuat pengunjung dating lagi dan lagi keperpustakaan. Pustakawan dapat membuat suasana perpustakaan senyaman mungkin. Bukan hanya fasilitas dan kelengkapan bahan pustaka, akan tetapi program pencarian informasi elektronik juga harus dipersiapkan oleh pustakawan. Pustakawan juga dapat membuat ruangan audio visual yang dapat digunakan untuk menayangkan film dan juga sebagai tempat pembelajaran dengan media visual. Kemajuan teknologi dan informasi harus menjadi langkah baru dalam kegiatan perpustakaan seperti bidang layanan, pencarian informasi, pengolahan bahan pustaka, alih media bahan pustaka langka 
sehingga kerusakannya bisa diminimalkan karena pengunjung bisa membaca yang sudah dialihmediakan.

Pustakawan kreatif inovatif merupakan pustakawan yang mampu menguraikan kompleksitas tantangan dan memikirkan berbagai alternatif tindakan yang dapat dilakukan di era digital dan bekerja keras untuk kemajuan perpustakaan agar tidak tertinggal dari Negara lain. Mereka selalu berpandangan positif dengan berorientasi kedepan terhadap suatu persoalan yang merupakan kunci awal untuk membangun kreatifitas.

Kreatifitas bukanlah bakat yang dianugerahkan sejak lahir, melainkan sesuatu yang harus diupayakan dengan kerja keras. Dikatakan bahwa orang kreatif adalah mereka yang memiliki disiplin tinggi untuk terus menciptakan dan melahirkan ide-ide baru. Pustakawan di era digital menghadapi permasalah kompleks. Oleh karena itu mereka dituntut memiliki keahlian yang bisa menjadi bekal untuk mengekplorasi kreativitas dalam mencari dan mengevaluasi informasi kritis serta inovasi dalam bekerja secara produktif.

Menurut (Purwono, 2013) ada dua aspek profil pustakawan Indoensia (sebagai pustakawan ideal) yang sangat menarik yaitu: (1) aspek professional, yang meliputi gemar membaca, terampil, kreatif, cerdas dan tanggap. (2) aspek kepribadian dan perilaku, yang meliputi ketakwaan kepada Tuhan Yang Maha Esa, bermoral, memiliki etos kerja yang baik, loyalitas terhadap profesi, tanggap terhadap perkembangan teknologi informasi. Kedua aspek diatas merupakan aspek yang membentuk menjadi pustakawan profesioanal dibidangnya. 


\section{Simpulan}

Perkembangan ilmu pengetahuan dan teknologi harus dimanfaatkan dengan baik oleh pengelola perpustakaan untuk pengembangan perpustakaan digital. Fenomena era digital akan mengubah cara kerja perpustakaan konvesional menjadi perpustakaan digital yang sekarang sedang berkembang. Perpustakaan tidak lagi melakukan pengelolaan perpustakaan secara manual. Semua bidang kerja di harapkan berbasis digital seperti bagian layanan, bagian pengolahan, sistem pencarian informasi dan bagian lainnya. Melihat kondisi perpustakaan seperti diatas, pustakawan harus mempersiapkan diri dengan cara mengisi diri dengan berbagai ilmu dibidang kepustakawanan, melek informasi, mengikuti perkembangan teknologi informasi dan yang tidak kalah penting adalah character bulding. Dengan berkarakter baik seorang pustakawan diharapkan mampu melaksanakan tugas-tugasnya dengan tanggung jawab serta professional dibidangnya.

Sikap dan budaya kerja pustakawan perlu dirubah agar sesuai dengan era digital yang berkembang sekarang, yang menuntut pustakawan bekerja dengan cepat, tepat dan efisien. Momentum reformasi bisa dimanfaatkan untuk melakukan reformasi di perpustakaan menuju perpustakaan digital berinklusi sosial, seperti yang dicanangkan Perpustakaan Nasional RI sekarang ini. Dalam era ferormasi ini, selain padat karya dan padat modal maka padat teknologi di perpustakaan perlu digiatkan dan dikreasikan. Pustakawan harus mengikuti perkembangan ilmu pengetahuan dan teknologi dengan memanfaatkan kemudahan fasilitas, sarana dan informasi dewasa ini. 


\section{Daftar Pustaka}

Akadun. (2009). Teknologi Informasi Administrasi. Bandung: Alfabeta Bandung.

Hartono. (2016). Manajemen Sumber Informasi Pepustakaan. Yogyakarta: Calpulis.

Hermawan, R., \& Zen, Z. (2006). Etika Kepustakawanan: Suatu Pendekatan Terhadapa Kode Etik Pustakawan Indonesia. Jakarta: Sagung Seto.

Perpustakaan Nasional RI. (2010). Undang-Undang Republik Indonesia Nomor 43 Tahun 2007 Tentang Perpustakaan. Jakarta: Perpustakaan Nasional RI.

Purwono. (2013). Profesi Pustakawan Menghadapi Tantangan Perubahan. Yogyakarta: Graha Ilmu.

Rhoni. (2017). Pustakawan Profesional di Era Digital. Yogyakarta: Suluh Media.

Salmubi. (2005). Membangun Kepustakawanan Indonesia: Tugas dan Tanggung Jawab Pustakawan Profesional pada Era Informasi. Surakarta: Makalah Rapat Kerja dan Seminar Ilmiah Nasional Ikatan Pustakawan Indonesia.

Sedharmayanti. (2014). Pengembangan Kepribadian Pegawai. Bandung: Mandar Maju.

Soemarno, S. (2014). Character Building: Membentuk Watak. Jakarta: Gramedia.

Sujatna. (2018). Inovasi Pustakawan Zaman Now. Tanggerang: Mahara Publishing.

Sutopo, A. H. (2012). Teknologi Informasi dan Komunikasi dalam Pendidikan. Yogyakarta: Graha Ilmu.

Suwarno, W. (2010). Ilmu Perpustakaan \& Kode Etik Pustakawan. Yogyakarta: Ar-Ruzz Media.

Uno, H. B. (2007). Teori Motivasi \& Pengukurannya. Bumi Aksara.

Yahya, M. (2013). Profesi Tenaga Kependidikan. Bandun: Pustaka Setia. 